Ирена Г. Петровић ${ }^{1}$

УДК $330.11: 517.16(497.11)$

Вера Д. Бацковић²

Универзитет у Београду

Филозофски факултет

Одељење за социологију

https://doi.org/10.18485/ssd_sddc.2021.ch8

\title{
ПРОСТОРНА ДИМЕНЗИЈА ЕКОНОМСКИХ НЕЈЕДНАКОСТИ У СРБИЈИ: КОМПАРАТИВНА ПЕРСПЕКТИВА
}

Апстракт: Територијалне неједнакости у степену економског развоја представљају неоспорну чињеницу која карактерише савремена друштва. Ипак, истраживања која се баве економским неједнакостима у простору, као и њиховим последицама на услове живота и животне шансе појединаца и друштвених група представљају реткост, поготово у домаћој научној заједници. Циљ овог рада је анализа одређених просторних аспеката економских неједнакости у Србији, али и поређење Србије са земљама у региону и земљама Европске уније. Поред истраживања неједнакости у приходима, пратиће се и регионалне разлике на тржишту рада. Неједнакости ће се пратити на нивоу различитих територијалних целина (региона и области), односно НСТJ-2 и НСТJ-3 нивоу. Анализа ће, између осталог, бити заснована на подацима Анкете о радној снази коју у Србији спроводи Републички завод за статистику, а која се реализује према стандардизованој методологији која се примењује у свим државама чланицама Европске уније, као и подацима Еуростата.

Кључне речи: просторна димензија; регионалне неједнакости; Србија; Европска унија.

\section{Увод}

Територијалне, односно регионалне неједнакости у степену економског развоја представљају неоспорну чињеницу која карактерише савремена друштва. У том смислу, ни Србија не представља изузетак. Упркос томе, истраживања која се баве економским неједнакостима у простору, као и њиховим последицама на услове живота и животне шансе појединаца и

\footnotetext{
1 irena.petrovic@f.bg.ac.rs

2 vera.backovic@f.bg.ac.rs
} 
друштвених група представљају реткост, поготово у домаћој научној заједници ${ }^{3}$.

Србију карактеришу не само изражене регионалне неједнакости, већ и њихов континуитет, као и постојаност односа развијених и неразвијених области; у Србији тако постоје тзв. традиционално неразвијена подручја, односно општине (претежно на југу земље) које деценијама уназад имају статус неразвијених подручја (више у Molnar, 2013б: 230).

Регионални диспаритети присутни су у многим сферама друштвеноекономског живота (економској, политичкој, образовној, здравственој итд.). Овај рад ће се, пак, првенствено бавити анализом економских неједнакости према различитим просторним/територијалним целинама у Србији, али и поређењем Србије са земљама региона и земљама Европске уније (у даљем тексту ЕУ). Осим анализе обима регионалних неједнакости, у раду се указује и на узроке регионалних неравномерности.

Значај анализе регионалних неједнакости, односно укључивање мањих просторних целина, као оквира анализе унутар националних држава, указује на могући допринос превазилажењу ограничења "методолошког национализма" и бољег разумевања пораста и трансформације друштвених неједнакости у контексту савремене глобализације (Petrović i dr, 2019). Такав приступ је од нарочитог значаја за европска пост-социјалистичка друштва за која су карактеристични већи унутрашњи развојни раскораци у простору. У исто време, просторне неједнакости у овим земљама бележе бржи пораст у односу на развијеније земље ЕУ (Hadjimichalis, 2011).

Економске неједнакости могуће је пратити на основу различитих макроекономских показатеља, попут бруто домаћег производа, стопе инвестиција, стопе запослености и незапослености итд. У овом раду, поред истраживања неједнакости у дохоцима (помоћу бруто друштвеног производа по глави становника, просечне зараде), пратиће се и регионалне разлике на тржишту рада (преко стопе запослености, стопе незапослености итд.). Неједнакости ће се пратити на нивоу ужих територијалних подручја

3 Изузев радова М. Арандаренка (2006, 2007, 2021. итд.), Д. Молнара (2013 итд.), М. Петровић и др. (2019). 
(региона и области), за које су подаци доступни, односно НСТJ-2 и НСТJ-3 нивоу. 4

Анализа ће, између осталог, бити заснована на подацима Анкете о радној снази коју у Србији спроводи Републички завод за статистику, а која се реализује према стандардизованој методологији која се примењује у свим државама чланицама ЕУ, као и подацима Еуростата.

\section{Појмовно-теоријски оквир}

Историјски посматрано, индустријализација је узроковала неједнаки регионални развој (иако се процес није одвијао у исто време и истим темпом у европским државама). У оквиру политике државе благостања у другој половини 20. века пажња се донекле посвећивала смањењу просторних неједнакости инвестирањем у инфраструктуру - саобраћајну, комуналну, образовну, здравствену (Petrović i dr, 2019). Креирањем политике регионалног развоја међу првима су почеле да се баве управо оне земље које су се суочавале са израженим регионалним неједнакостима (попут Шведске, Италије, Француске и Уједињеног Краљевства). Нешто касније, почев од 70их година прошлог века, важан допринос на овом пољу је произашао као резултат Регионалне политике ЕУ, која је установљена након уласка Уједињеног Краљевства у ЕУ (Molnar, 2013б: 317-318). Када је реч о социјалистичким земљама, оне су настојале да планским усмеравањем средстава уравнотеже неједнак развој региона. Између осталог, ове земље су се суочавале са економском/индустријском неразвијеношћу, наслеђеним

4 Номенклатура статистичких територијалних јединица (НСT) (енг. Nomenclature of Units for Territorial Statistics (NUTS) садржи три нивоа: НCTJ 1, НCTJ 2, НCTJ 3. Реч је о статистичким јединицама које су, у складу са стандардима ЕУ, разврстане према следећим критеријумима: 1) броју становника; 2) геополитичкој позицији; 3) природним потенцијалима; 4) постојећој територијалној организацији и 5) културноисторијском наслеђу (Уредба о НТСJ, 2009: члан 3). НСТЈ нивои су дефинисани на основу броја становника: НСТЈ 1 3.000.000-7.000.000; НСТЈ 2 800.000-3.000.000 и НСТ 3 150.000-800.000. Србија је подељена на два НСТЈ1 региона, Србија-север и Србија-југ. Функционалне целине нивоа НСТЈ 1 чине територијалне јединице - региони нивоа НСТЈ 2, и то: 1. Београдски регион; 2. Регион Војводине; 3. Регион Шумадије и Западне Србије; 4. Регион Јужне и Источне Србије; 5. Регион Косова и Метохије (Уредба НСТЈ 2009, члан 7). У анализи регионалних неједнакости није обухваћен регион Косова и Метохије. 
неједнаким просторним развојем, као и неједнаким развојем који је изазвала интензивна индустријализација током социјализма 5 .

Крајем 20. века неолиберална глобализација и ширење информационих технологија доносе ново преобликовање простора, подстичући деиндустријализацију градова економски најразвијенијих земаља, развој сервисне и креативне економије и концентрацију управљања и напредних сектора сервисне економије и услуга у њима (Castells, 2000; Florida, 2002; Friedmann, 1995; Sassen, 1991). У том периоду социјалистичке земље улазе у процес пост-социјалистичке трансформације, док је њихова политичка и економска трансформација и стабилизација омогућила да главни градови и велики метрополитенски центри постану место уласка капитала на територију њихових земаља (Backović, 2010; Петровић, 2009;).

Међутим, процес деиндустијализације у случајевима постсоцијалистичких градова обухватао је пропаст индустрије ${ }^{6}$ (Domanski, 2011; Шљукић, 2018), а не њену преоријентацију на нове секторе. Последично, дошло је до повећавања регионалних неједнакости у овим земљама посебно између главног града и осталих делова. Показатељи раста и развоја, попут БДП-а по глави становника, стопе запослености итд., главних градова и одређених региона постали су значајно виши од националног просека (према Petrović i dr, 2019; Petrović, 2014; Huber, 2007). Реч је о регионима који су се развијали знатно брже и вредности њихових кључних развојних индикатора приближавали су се просеку ЕУ, док су региони који нису

5 Управо су у Југославији током социјалистичког периода биле присутне натпросечне међурегионалне разлике у зарадама. У периоду од 1963-1983. године просечни месечни лични дохоци у Словенији били су за приближно једну петину већи од југословенског просека, док су Македонија и Косово једва прелазили износ од 80\% општег просека (Mrkšić, 2000: 250). Налази одређених истраживања (Ocić, 2004) показују да су се регионалне разлике у Југославији током периода 1952-1988. година смањивале у случају запослености и основних средстава (основна средства по радно способном становнику), а да су се повећавале када је у питању друштвени производ по становнику (према Molnar, 2013б: 294).

${ }^{6} \mathrm{C}$ једне стране, индустријски сектор, а самим тим и индустријски градови изгубили су привилегован приступ ресурсима који су имали током социјализма, док су, с друге стране, изложени међународној конкуренцији. У том процесу посебно су били погођене текстилна, тешка и војна индустрија (Domanski, 2011). 
бележили такав раст остали на маргинама (Hadjimichalis, 2011). У том периоду на нивоу ЕУ уочава се раст регионалних неједнакости, како унутар држава чланица, тако и између држава. Овај тренд се нарочито појачао после 2000. године и уласка пост-социјалистичких земаља у ЕУ (Domanski, 2011; Hadjimichalis, 2011; Perrons, 2011; Tomaney et al., 2011)73.

На пораст регионалних неједнакости унутар пост-социјалистичких земаља утицали су наслеђен степен индустријског развоја из социјалистичког периода и специфичности социо-економске трансформације - увођење тржишне економије, приватизација, реституција, реиндустријализација и редефинисање принципа социјалне државе. Као добитници овог процеса издвојила су се метрополитенска подручја ${ }^{8}$, са растућим услужним сектором, развијеном инфраструктуром, висококвалификованом радном снагом и сл. Са друге стране, са највећим проблемима суочили су се моно-индустријски градови (у којима је пропала индустрија) и мањи, удаљени градови са неразвијеном саобраћајном инфраструктуром (Domanski, 2011; Petrović, 2014; Petrović i dr. 2019). Управо су се ови (моно-индустријски градови) суочили са великим порастом незапослености ${ }^{9}$.

Регионалне неједнакости су у великој мери обележиле и процес постсоцијалистичке трансформације у Србији. Специфичност Србије која је додатно отежала овај процес јесте период блокиране пост-социјалистичке

7 Управо су у пост-социјалистичким земљама забележене велике регионалне разлике на тржишту рада (опширније у Huber, 2007).

8 Бржи развој главног града и метрополитенског подручја у односу на мање градове и руралне области може се објаснити утицајем међународне трговине, страним директним инвестицијама и разним факторима агломерације. Наиме, у почетној фази економског реструктурирања највећи део јавних инвестиција углавном се намерно усмеравао на најефикасније пројекте, од којих је већина лоцирана у областима националног раста. С друге стране, недостатак инвестиција у мање развијене регионе, као и брзо привредно реструктурирање, које утицало на раст незапослености, допринели су повећавању регионалних диспаритета у пост-социјалистичким земљама (Arandarenko, Jovičić, 2007:301).

9 Примера ради, у Бугарској и Молдавији запосленост је расла искључиво у регионима главних градова, у Хрватској је забележен пораст само у четири од 21 региона, а у Пољској у три од 16 региона у Пољској (World Bank, 2005, према Arandarenko (ур.), 2006: 9-10). 
трансформације током деведесетих година, уз драматичан пад друштвеног производа и индустријске производње, хиперинфлацију, пораст незапослености итд. (Lazić, Cvejić, 2004). Процеси секторске и својинске трансформације који су обележили овај период нису се одразили само на пад запослености и пораст незапослености, већ су, између осталог, проузроковали и раст већ постојећих регионалних неједнакости. Традиционално неразвијеном југу Србије придружила су се некада развијена индустријска подручја (источна Србија, делови централне Србије, регионални центри рударства), постајући тако нова подручја неразвијености (Arandarenko, Nojković, 2007, 28-29).

Ипак, без обзира на дуготрајно присуство регионалних неједнакости у Србији, овом проблему се није посвећивала одговарајућа пажња. Тако је тек у 2004. години решавање проблема регионалних диспаритета на тржишту рада постао један од приоритетних циљева Националне стратегије запошљавања за период 2005-2010. године. Подстицање запошљавања у мање развијеним регионима представљао је један од приоритетних циљева наведене стратегије и за наредни период (20112020) (Arandarenko, Nojković, 2007: 41). Међутим, реализацију ових циљева отежавале су дугогодишње регионалне неравномерности у Србији, које су биле, као што је претходно речено, изражене и пре почетка трансформацијског периода. Регионалне диспропорције у Србији након 2000. године, мерене индексом развојне угрожености, биле су међу највећим у Европи; регионалне разлике у 2005. години, посматране на нивоу округа (НСТЈ-3 ниво) износиле су 1:7, док је однос најразвијеније и најнеразвијеније општине (НСТ)-4 ниво) износио чак 1:15 (Стратегија регионалног развоја РС за период од 2007. до 2012. године, 2007: 84). Овај период је обележен и порастом јаза између београдског и новосадског метрополитенског подручја и других градова. Тада је Београдски регион привукао највећи број домаћих и страних инвестиција, док је у осталим регионима дошло до драстичног пада индустријске производње и пропасти индустријских градова (Молнар, 2013а).

Може се уочити да се овај тренд и даље наставља; према најновијим подацима (Arandarenko et al., 2021:207), расподела укупних средстава страних директних инвестиција поново указује на неравномерну расподелу: највећи део средстава додељен је Региону Војводине (34\%), 
затим Београда (25\%), док преостала два региона бележе мање учешће (по $21 \%)$.

У наставку рада биће најпре приказани основни економски показатељи (БДП по глави становника, просечна зарада, основни индикатори тржишта рада), док ће у другом делу рада анализа бити усмерена на поређење Србије са земљама у региону и земљама ЕУ.

\section{Регионалне неједнакости у Србији: анализа основних економских показатеља}

Регионални бруто домаћи производ представља кључни статистички показатељ за мерење економских перформанси региона. Подаци из 2019. године који се односе на учешће региона у стварању БДП-а показују да Београдски регион заузима водеће место са 41,7\% (Табела 1). Имајући у виду да Београдски регион обухвата скоро 4\% територије на којој живи једна четвртина становника Србије, јасно је да је реч о региону са највећим БДП-ом по становнику10. Иза Београдског региона следи регион Војводине, чије учешће у укупном БДП-у износи 26,5\%. Индекс нивоа БДП-а по глави становника за Регион Војводине у вредности од 99,4\% показује да је овај регион готово изједначен са републичким нивоом (РЗС, 2021a: 10).

Са друге стране, учешће преостала два региона креће се испод 20\% (регион Шумадије и Западне Србије учествује са 18,1\%, док је учешће региона Јужне и Источне Србије свега $13,7 \%$ ). У исто време, ови региони бележе исподпросечне вредности БДП-а по становнику. За Регион Шумадије и Западне Србије индекс нивоа је $65,8 \%$, док је за Регион Јужне и Источне Србије индекс нивоа 63,8\%.

10 Са 1.332.000,00 динара БДП-а по глави становника, Београдски регион има за 70,8\% већи per capita износ у односу на републички ниво (РЗС, 2021a: 10). 
Табела 1. Регионални БДП, учешће региона у стварању БДП-а РС и индексни ниво (према НУТС-2)

\begin{tabular}{|c|c|c|c|c|c|c|c|c|c|}
\hline & \multicolumn{2}{|c|}{$\begin{array}{c}\text { БДП } \\
\text { (мил. РСД) }\end{array}$} & \multirow{2}{*}{$\begin{array}{c}\text { Индекс } \\
\text { 2019/18 }\end{array}$} & \multicolumn{2}{|c|}{$\begin{array}{c}\text { Учешће } \\
\text { (\%) }\end{array}$} & \multicolumn{2}{|c|}{$\begin{array}{c}\text { БДП по } \\
\text { становнику } \\
\text { (хиљ. РСД) }\end{array}$} & \multicolumn{2}{|c|}{$\begin{array}{c}\text { БДП по } \\
\text { становнику } \\
\text { - индекс } \\
\text { нивоа } \\
\text { РС=100 }\end{array}$} \\
\hline & 2019 & 2018 & & 2019 & 2018 & 2019 & 2018 & 2019 & 2018 \\
\hline СРБИЈА & 5417725 & 5072932 & 106,8 & 100,0 & 100,0 & 780 & 727 & 100,0 & 100,0 \\
\hline $\begin{array}{l}\text { Београд. } \\
\text { регион }\end{array}$ & 2257001 & 2097607 & 107,6 & 41,7 & 41,3 & 1332 & 1241 & 170,8 & 170,8 \\
\hline $\begin{array}{l}\text { Регион } \\
\text { Војводи. } \\
\text { Шумадија }\end{array}$ & 1436403 & 1314080 & 109,3 & 26,5 & 25,9 & 776 & 706 & 99,4 & 97,1 \\
\hline $\begin{array}{l}\text { и Запад. } \\
\text { Србија } \\
\text { Јужна и }\end{array}$ & 980388 & 941439 & 104,1 & 18,1 & 18,6 & 514 & 489 & 65,8 & 67,3 \\
\hline $\begin{array}{l}\text { Источна } \\
\text { Србија }\end{array}$ & 741290 & 717110 & 103,4 & 13,7 & 14,1 & 497 & 476 & 63,8 & 65,6 \\
\hline
\end{tabular}

Извор: РЗС, 2021а: 10. Регионални бруто домаћи производ, Региони и области Републике Србије, 2019.

Регионалне неравномерности у Србији посебно долазе до изражаја уколико се прате разлике на ужим регионалним нивоима (областима и општинама). Подаци P3C-а показују да учешће Београдске и Јужнобачке области заједно у укупном БДП-у прелази $50 \%$ (учешће Јужнобачке области у укупном БДП-у креће се око 11\%). Потом следе Сремска (4,2\%), Нишавска (3,7\%), Јужнобанатска (3,6\%), Шумадијска област $33,0 \%)$ итд. Са друге стране, најнеразвијеније области су Пиротска, Зајечарска и Топличка (учешће у укупном БДП-у је испод 1\%) (Р3С, 2021a:15). Према подацима Еуростата, ове области су уједно и најнеразвијеније у Европи (видети табелу 1 у прилогу).

Развијеност региона можемо пратити и на основу просечних зарада. Степен развијености региона, мерен просечним зарадама (без пореза и доприноса), креће се у размери 1,5: 1, при чему су највише зараде забележене у Београдском региону, док становници Шумадије и Западне Србије имају најниже зараде. У Београдском региону 2020. године просечна зарада износила је 74311 динара или 124\% републичког просека. Регион Војводине се налази нешто испод републичког просека (95\%), док су преостала два региона остварила око 87\% националног просека. Када се 
посматра ниво општина, подаци Р3С-а показују да су у 60 општина просечне зараде биле испод 80\% републичког просека (РЗС, 20216, 60) ${ }^{11 .}$

Регионалне диспропорције се уочавају и када се прате основни показатељи тржишта рада ${ }^{12}$. Готово сви показатељи за све три категорије становништва указују на повољнију позицију Београдског региона, док су најлошије перформансе забележене у региону Јужне и Источне Србије. Разлике су посебно изражене када посматрамо стопу запослености и незапослености. У Београдском региону је нешто виша општа стопа запослености и нижа стопа незапослености, осим за категорију младог становништва, где је најповољнија ситуација у Војводини. Уколико посматрамо стопу незапослености, можемо видети да регион Јужне и Источне Србије са стопом незапослености од скоро $12 \%$ (за становништво старије од 15 година) за 28\% превазилази просек Србије (који износи 9\%), док је у Београдском региону стопа незапослености најнижа - 7,5\%, односно $17 \%$ испод републичког просека (Р3С, 2021б, 60). Ако се анализирају кретања на тржишту рада у последњој деценији, уочава се пораст запослености у свим регионима, с тим да је запосленост најбрже расла у Београдском региону, тако да се повећао јаз између овог и преостала три региона (са друге стране, разлика између ова три региона незнатно се смањила). Овај налаз могли бисмо да објаснимо концентрацијом нових радних места у мање развијеним регионима. Заправо, већина нових радних места (у периоду од 2016-2020) која су резултат страних директних инвестиција отворена је у два мање развијена региона - Шумадији и Западној Србији и Јужној и Источној Србији (по 31\%), док је нешто мање учешће нових радних места забележено у Војводини (21\%) и Београду (18\%) (Arandarenko et. al, 2021: 208) ${ }^{13}$.

Могло би се, дакле, укратко закључити да постоје одређене регионалне разлике на тржишту рада у Србији. Оно што се, ипак, никако не

11 Најнеразвијеније општине су Власотинце, Сврљиг и Гаџин Хан, где су просечне зараде прошле године биле нешто више од 40000 динара (РЗС, 2021b: 60).

12 0 регионалним неједнакостима на тржишту рада у Србији и карактеристикама незапослености према регионима видети још Petrović, 2013.

13 Директне стране инвестиције претежно су биле усмерене на индустријски сектор (о дистрибуцији ДСИ и нових радних места према делатностима детаљно у Arandarenko et. al, 2021: 207-208). 
може изгубити из вида јесте то да су, на основу посматраних показатеља тржишта рада, варијације између четири региона недовољно изражене. Када се прате основни индикатори тржишта рада на ужим регионалним нивоима, односно нивоу области (НУТС-3 територијалних целина) тада међурегионалне разлике долазе до пуног изражаја (више у Molnar, 2013: 336-338).

Табела 2. Становништво према региону, статусу активности и старосним групама, 2020. године (у \%)

\begin{tabular}{|c|c|c|c|c|c|}
\hline Индикатори & $\begin{array}{c}\text { Београд. } \\
\text { регион }\end{array}$ & $\begin{array}{c}\text { Регион } \\
\text { Војводине }\end{array}$ & $\begin{array}{c}\text { Регион } \\
\text { Шумадије и } \\
\text { Западне } \\
\text { Србије }\end{array}$ & $\begin{array}{c}\text { Регион } \\
\text { Источне и } \\
\text { Јужне Србије }\end{array}$ & Укупно \\
\hline \multicolumn{6}{|c|}{ Становништво старо 15 и више година } \\
\hline Стопа активности & 55,5 & 52,4 & 55,9 & 51,7 & 54,0 \\
\hline Стопа запослености & 51,3 & 48,5 & 50,4 & 45,8 & 49,1 \\
\hline $\begin{array}{l}\text { Стопа } \\
\text { незапослености }\end{array}$ & 7,5 & 7,6 & 9,8 & 11,5 & 9,0 \\
\hline Стопа неактивности & 44,5 & 47,6 & 44,1 & 48,3 & 46,0 \\
\hline \multicolumn{6}{|c|}{ Младо становништво (15-24) } \\
\hline Стопа активности & 28,2 & 30,2 & 27,7 & 26,9 & 28,3 \\
\hline Стопа запослености & 21,4 & 23,3 & 20,0 & 17,9 & 20,8 \\
\hline $\begin{array}{l}\text { Стопа } \\
\text { незапослености }\end{array}$ & 24,1 & 22,8 & 27,7 & 33,4 & 26,6 \\
\hline Стопа неактивности & 71,8 & 69,8 & 72,3 & 73,1 & 71,7 \\
\hline \multicolumn{6}{|c|}{ Становништво радног узраста (15-64) } \\
\hline Стопа активности & 70,4 & 66,4 & 68,4 & 65,4 & 67,7 \\
\hline Стопа запослености & 65,0 & 61,2 & 61,0 & 57,3 & 61,3 \\
\hline $\begin{array}{l}\text { Стопа } \\
\text { незапослености }\end{array}$ & 7,7 & 7,8 & 10,7 & 12,4 & 9,5 \\
\hline Стопа неактивности & 29,6 & 33,6 & 31,6 & 34,6 & 32,3 \\
\hline
\end{tabular}

Извор: РЗС, АРС, 2021с, стр. 14

Сагледавање односа екстремних (највиших и најнижих) вредности кључних индикатора пружа потпунију слику регионалне асиметричности. Однос екстремних вредности показује да су разлике знатно боље изражене у случају БДП-а по глави становника него осталих показатеља економске развијености (просечне нето зараде и стопе незапослености, на пример). Као што можемо да видимо, БДП по глави становника у Београдском региону је готово три пута већи него у региону Јужне и Источне Србије. 
Регионалне асиметричности се јасно препознају и када се прате остали показатељи; као што смо претходно могли да видимо, разлике су посебно уочљиве између Београдског региона и региона Јужне и Источне Србије.

Табела 3. Екстремне вредности индикатора регионалне асиметричности, 2020. године

\begin{tabular}{|c|c|c|c|c|c|c|}
\hline 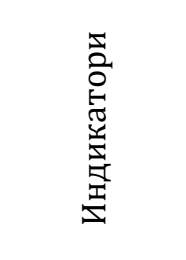 & 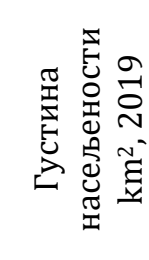 & 点 & 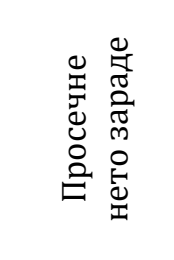 & 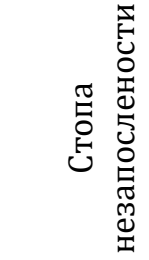 & 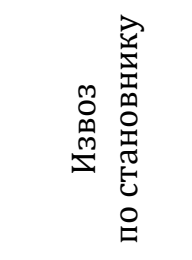 & 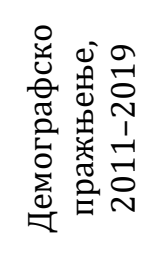 \\
\hline \multirow[b]{2}{*}{$\begin{array}{c}\text { Екстремне } \\
\text { вредности } \\
\text { (највиша: } \\
\text { најнижа) }\end{array}$} & $9: 1$ & $2,7: 1$ & $1,5: 1$ & $1,6: 1$ & $1,7: 1$ & $\begin{array}{l}(-7,6): \\
(+2,2)\end{array}$ \\
\hline & $\begin{array}{l}\text { Београд. } \\
\text { регион: } \\
\text { Регион } \\
\text { Јужне и } \\
\text { Источне } \\
\text { Србије }\end{array}$ & $\begin{array}{l}\text { Београд. } \\
\text { регион: } \\
\text { Регион } \\
\text { Јужне и } \\
\text { Источне } \\
\text { Србије }\end{array}$ & $\begin{array}{l}\text { Београд. } \\
\text { регион: } \\
\text { Регион } \\
\text { Шумадије } \\
\text { и Западне } \\
\text { Србије }\end{array}$ & $\begin{array}{l}\text { Регион } \\
\text { Јужне и } \\
\text { Источне } \\
\text { Србије: } \\
\text { Београд. } \\
\text { регион }\end{array}$ & $\begin{array}{l}\text { Регион } \\
\text { Војводине: } \\
\text { Регион } \\
\text { Јужне и } \\
\text { Источне } \\
\text { Србије }\end{array}$ & $\begin{array}{l}\text { Регион } \\
\text { Јужне и } \\
\text { Источне } \\
\text { Србије: } \\
\text { Београд. } \\
\text { регион }\end{array}$ \\
\hline
\end{tabular}

Извор: РЗС (2021б), Трендови, IV квартал 2020, стр. 62.

\section{Србија у компаративној перспективи}

У циљу потпуније анализе регионалних неједнакости у Србији, у наставку рада Србија ће бити смештена у упоредни оквир, односно биће приказани подаци за земље у региону и за земље ЕУ. У следећој табели (Табела 4) представљен је регионални БДП изражен у паритету куповне снаге (енг. the purchasing power standard - PPS), а региони Републике Србије се посматрају у односу на индикаторе ЕУ-28 (подаци су дати за 2018. и 2019. годину). Видимо да је Србија на нивоу од 40\% просека БДП-а по становнику у ЕУ. Београдски регион се налази на нивоу од 69,3\%, следи Војводина са 40,3\%, док је најнеразвијенији регион Србије - Регион Јужне и Источне Србије на нивоу од само 25,9\% просека БДП-а по глави становника у земљама ЕУ.

Добијени подаци говоре у прилог претходно изнетих теоријских и емпиријских запажања да се одређена градска, метрополитенска подручја (у овом случају Београдски регион) развијају брже од осталих региона, знатно превазилазећи национални просек. 
Табела 4. Регионални БДП Србије vs. ЕУ 28 - ППС

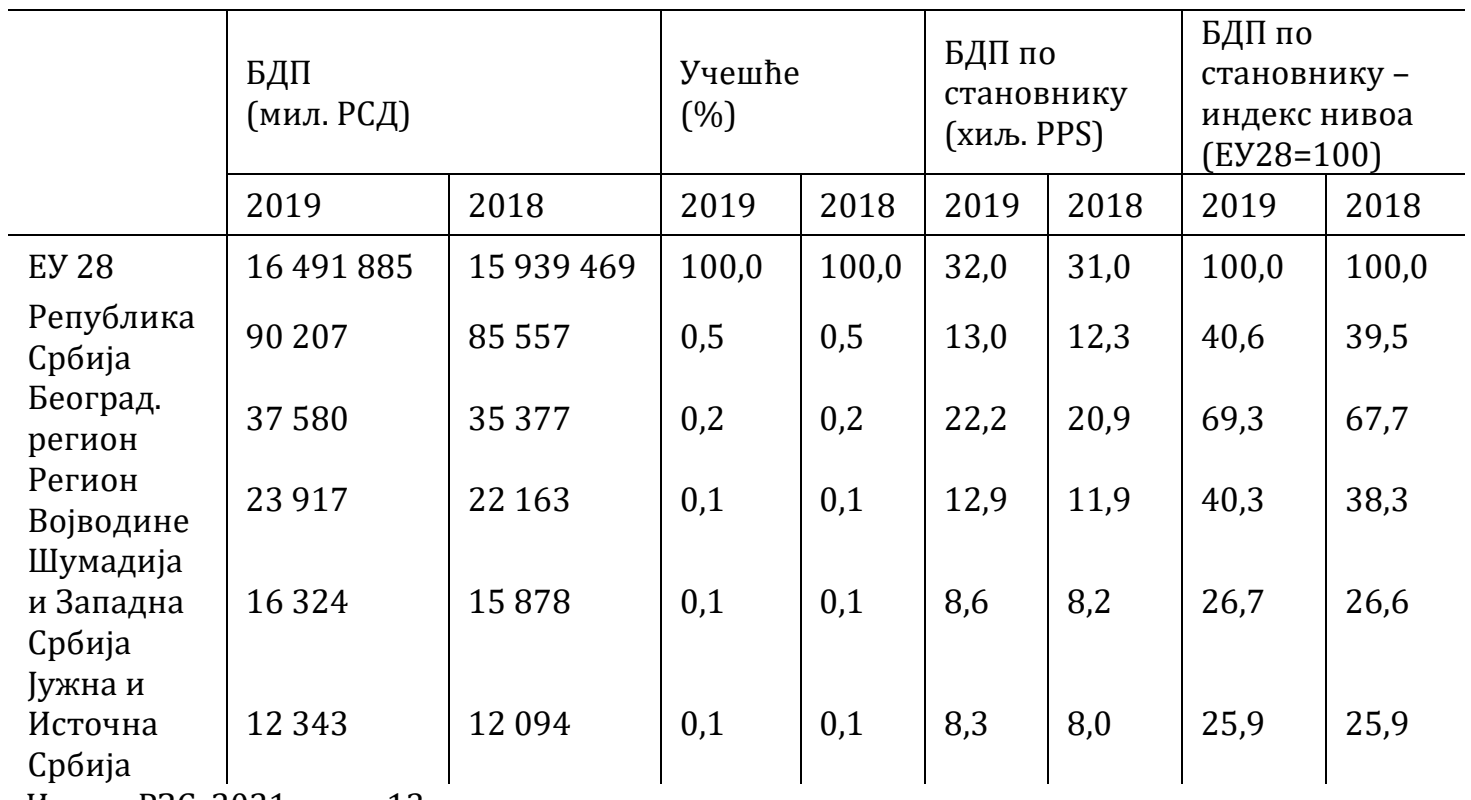

Уколико посматрамо земље у региону (Табела 5), можемо видети да се једино регион Западне Словеније налази изнад просека БДП - по глави становника у ЕУ - 27. Поређењем Србије са земљама у региону, уочава се да Северна Македонија и Албанија (посебно северни део ове земље) заузимају лошији положај, док је Хрватска знатно боље позиционирана (индекс нивоа за 2019. годину за ову земљу је 65). Можемо такође видети и да Црна Гора заузима бољу позицију од Србије. Овде ја важно још једно запажање. Праћењем кретања овог показатеља у последњој деценији (2010-2019), можемо видети да су Хрватска, Словенија, али и Црна Гора у одређеној мери побољшале своју позицију, док у Србији, Македонији и Албанији нису приметне значајније промене. Ако се има у виду класификација региона Европске комисије на основу БДП-а по глави становника, према којој у мање развијене регионе спадају региони чији је БДП по становнику испод нивоа од 75\% просека ЕУ (више у Molnar, 2013а: 327), видимо да готово све посматране земље (изузев Словеније) и даље задржавају позицију неразвијених подручја. Исти закључак се односи и на Београдски регион; иако овај регион у великој мери превазилази национални просек, он се и даље налази испод просека земаља ЕУ. 
Табела 5. Стандард куповне снаге (ППС)

\begin{tabular}{|c|c|c|c|c|c|c|c|c|c|c|}
\hline Области & 2010 & 2011 & 2012 & 2013 & 2014 & 2015 & 2016 & 2017 & 2018 & 2019 \\
\hline EУ - 27 & 100 & 100 & 100 & 100 & 100 & 100 & 100 & 100 & 100 & 100 \\
\hline Хрватска & 60 & 60 & 61 & 61 & 60 & 60 & 61 & 63 & 64 & 65 \\
\hline $\begin{array}{r}\text { Јадранска } \\
\text { Хрватска }\end{array}$ & 58 & 58 & 58 & 58 & 58 & 58 & 60 & 62 & 63 & 64 \\
\hline $\begin{array}{r}\text { Континентална } \\
\text { Хрватска } \\
\end{array}$ & 61 & 62 & 62 & 62 & 60 & 61 & 62 & 63 & 65 & 66 \\
\hline Словенија & 85 & 84 & 83 & 83 & 83 & 83 & 84 & 86 & 87 & 89 \\
\hline $\begin{array}{r}\text { Источна } \\
\text { Словенија }\end{array}$ & 69 & 69 & 69 & 69 & 69 & 69 & 69 & 71 & 72 & 73 \\
\hline $\begin{array}{r}\text { Западна } \\
\text { Словенија } \\
\end{array}$ & 102 & 101 & 100 & 99 & 99 & 99 & 100 & 102 & 105 & 106 \\
\hline Црна Гора & 41 & 42 & 40 & 41 & 41 & 43 & 45 & 46 & 48 & 50 \\
\hline $\begin{array}{l}\text { Северна } \\
\text { Македонија }\end{array}$ & 35 & 34 & 34 & 35 & 36 & 36 & 37 & 37 & 38 & : \\
\hline Албанија & 29 & 30 & 30 & 29 & 30 & 31 & 30 & 30 & 30 & : \\
\hline Север & 24 & 24 & 24 & 24 & 24 & 25 & 25 & 24 & 25 & : \\
\hline Центар & 38 & 36 & 36 & 35 & 36 & 37 & 35 & 36 & 37 & : \\
\hline Југ & 25 & 28 & 29 & 28 & 30 & 28 & 27 & 27 & 27 & : \\
\hline Србија & : & : & 40 & 41 & 40 & 39 & 39 & 39 & 40 & 41 \\
\hline Србија - север & : & : & 54 & 55 & 52 & 52 & 52 & 51 & 53 & 54 \\
\hline $\begin{array}{r}\text { Београдски } \\
\text { регион }\end{array}$ & : & : & 69 & 70 & 65 & 66 & 66 & 66 & 68 & 70 \\
\hline $\begin{array}{r}\text { Регион } \\
\text { Војводине }\end{array}$ & : & : & 41 & 41 & 41 & 39 & 39 & 39 & 39 & 41 \\
\hline Србија - југ & : & : & 26 & 27 & 27 & 26 & 26 & 26 & 26 & 26 \\
\hline $\begin{array}{r}\text { Регион } \\
\text { Шумадије и }\end{array}$ & : & : & 27 & 27 & 28 & 28 & 27 & 27 & 27 & 27 \\
\hline $\begin{array}{c}\text { Западне Србије } \\
\text { Регион Јужне и } \\
\text { Источне Србије }\end{array}$ & : & : & 25 & 26 & 25 & 24 & 24 & 25 & 26 & 26 \\
\hline
\end{tabular}

Извор: Еуростат. Gross domestic product (GDP) at current market prices by NUTS 2 regions. Purchasing power standard (PPS, EU27 from 2020), per inhabitant in percentage of the EU27 (from 2020) average https://appsso.eurostat.ec.europa.eu/nui/submitViewTableAction.do приступљено 6. августа 2021. 
Табела 6. Стопа запослености и незапослености $(\mathrm{y} \%)^{14}$

\begin{tabular}{r|l|l|l|l}
\hline \multirow{2}{*}{ Области } & \multicolumn{2}{l|}{ Стопа запослености } & \multicolumn{2}{l}{ Стопа незапослености } \\
\cline { 2 - 5 } & 2019 & 2020 & 2019 & 2020 \\
\hline ЕУ - 27 & 68,4 & 67,6 & 6,7 & 7,1 \\
\hline ЕУ - 28 & 69,2 & $:$ & 6,3 & $:$ \\
Хрватска & 62,1 & 62,0 & 6,6 & 7,5 \\
Јадранска Хрватска & 60,4 & 60,2 & 6,4 & 7,5 \\
Континентална Хрватска & 62,9 & 62,9 & 6,7 & 7,5 \\
Словенија & 71,8 & 70,9 & 4,5 & 5,0 \\
Источна Словенија & 70,4 & 69,7 & 4,9 & 5,5 \\
Западна Словенија & 73,5 & 72,1 & 4,0 & 4,4 \\
Црна Гора & 56,0 & $:$ & 15,2 & 17,9 \\
Северна Македонија & 54,7 & 54,7 & 17,3 & 16,4 \\
Србија & 60,7 & 61,3 & 10,5 & 9,1 \\
Србија - север & 62,7 & 63,0 & 8,7 & 7,6 \\
Београдски регион & 64,9 & 65,0 & 8,3 & 7,5 \\
Регион Војводине & 60,7 & 61,2 & 9,1 & 7,6 \\
Србија - југ & 58,6 & 59,4 & 12,4 & 10,7 \\
Регион Шумадије и & 59,9 & 61,1 & 11,8 & 10,0 \\
Западне Србије & & 57,3 & 13,3 & 11,7 \\
Регион уужне и Источне & 56,9 & &
\end{tabular}

Извор: Еуростат. Employment rates by sex, age and NUTS 2 regions (\%) https://ec.europa.eu/eurostat/databrowser/view/lfst_r_lfe2emprt/default/table?lang=en и Unemployment rates by sex, age, educational attainment level and NUTS 2 regions (\%)https://ec.europa.eu/eurostat/databrowser/view/LFST_R_LFU3RT_custom_1200689/defa ult/table?lang=en приступљено 6. августа 2021. године.

За крај, када се основни индикатори тржишта рада у Србији упореде са индикаторима држава чланица ЕУ-28 у 2019. години, уочава се неповољна ситуација. Општа стопа запослености у Србији је нижа за скоро 9 процентних поена (пп), док је разлика у стопи незапослености нешто мања (4 пп). Приликом анализе ових података свакако треба имати на уму квалитет запослености у Србији, односно значајно учешће прекарне

14 Подаци о запослености се односе на становништво старости од 15-64, а подаци о незапослености на становништво старости од 15-74. 
запослености ${ }^{15}$. Анализа карактеристика тржишта рада у земљама региона поново показује најповољнију позицију Словеније; оба региона ове земље имају нижу стопу незапослености од просека земаља ЕУ, док се Хрватска налази на нивоу просека земаља ЕУ. Са друге стране, у Црној Гори и Македонији стопа незапослености прелази 15\%, чиме се ове две земље смештају на само зачеље у Европи ${ }^{16}$.

\section{Закључак}

Имајући у виду да неуједначен економски раст доприноси продубљивању већ постојећих територијалних неједнакости, те да присуство регионалних диспаритета може имати негативне последице на укупан друштвено-економски развој једне земље (између осталог, изражене у виду економских миграција), проучавање размера и карактеристика регионалних неједнакости чини се неопходним.

Иако се анализа у овом раду претежно односила на испитивање међурегионалних разлика на нивоу НCTJ-2, овде је потребно указати и на изражену регионалну поларизацију на првом, НСТЈ- 1 нивоу, односно између северног и јужног дела земље, чему је посебно допринела разлика између најразвијенијих урбаних агломерација, Београда и Новог Сада, и остатка земље. Исто тако, диспаритети су се могли уочити и унутар региона (тј. на НСТЈ-3 нивоу), између развијених и неразвијених подручја, али и општина. Унутарегионални диспаритети посебно су присутни у неразвијеним регионима. Ако пратимо БДП по глави становника у Јужној и Источној Србији, показује се да је однос најразвијеније (Борске) и најнеразвијеније (Јабланичке) области 2,6:1, док су разлике у преосталим регионима знатно мање и крећу се у распону од 1,65:1 за области у региону Војводине до 1,74:1 за области које припадају региону Западне Србије и Шумадије ${ }^{17}$.

15 Налази Анкете о радној снази у Србији од 2014. године региструју пораст броја запослених на одређено време, који припадају прекарним облицима рада, уз истовремени пад удела запослених радника на неодређено време (према Marković, 2019: 127).

16 Нису доступни подаци о индикаторима тржишта рада за Албанију.

17 БДП за све области видети у Р3С, 2021a:14. 
Управо „разноликост“ регионалних неравномерности у Србији указује на важност истраживања регионалних неједнакости на различитим просторним целинама. Ово се посебно уочава на примеру проучавања економских неједнакости на ужим просторним подручјима (као што су области, али и општине). Анализом великих и развојно хетерогених просторних целина, као што су НУТС- 2 региони, или пак анализом националног нивоа, уочене разлике на најужим просторним оквирима остале би замагљене.

\section{Литература}

Arandarenko, M. (ur.). (2006). Mapa tržišta rada Srbije - ocena regionalnih razika i kvaliteta. Beograd: CEVES.

Arandarenko, M., A. Nojković (2007). Pregled tržišta rada u Srbiji. CDRSEE; NSHC.

Arandarenko, M., M. Jovičić (2007). Regional Labour Market Differences in Serbia: Assessment and Policy Recommendations. The European Journal of Comparative Economics, special issue on European regions, 2, pp: 299-317.

Arandarenko, M., Aleksić, D., Lončar, D. (2021). Expansion of direct investment and resilience of Serbian labour market: A regional and sectoral perspective. Ekonomika Preduzeća 69(3-4), pp: 203-216.

Backović, V. (2010). Socioprostorni razvoj Novog Beograda. Beograd: ISI FF.

Castells, M. (2000). Uspon umreženog društva, Zagreb: Golden marketing.

Domanski, B. (2011). Post-socialism and transition, In: Pike, A., RodriguezPose, A., Tomaney, J. (eds) Handbook of Local and Regional Development, Routledge, pp. 172-181.

Florida, R. (2002). The Rise of the Creative Class - And How It's Transforming Work, Leisure, Community and Everyday Life, New York: Basic Books.

Friedmann, J. (1995). The world city hypothesis, in: P. Knox and P. Taylor (eds.) World Cities in a World-System, Cambridge: Cambridge University Press, pp: 317- 332. 
Hadjimichalis, C. (2011). Uneven geographical development and sociospatial ju-stice and solidarity: European regions after the 2009 financial crisis. European Urban and Regional Studies, 18, pp: 254-274.

Huber, P. (2007). Regional Labour Market Developments in Transition: A Survey of the Empirical Literature. The European Journal of Comparative Economics, special issue on European regions, 2, pp: 263-299.

Lazić, M., Cvejić, S. (2004). Promene društvene strukture u Srbiji: slučaj blokirane postsocijalističke transformacije, u: A. Milić (prir.). Društvena transformacija i strategije društvenih grupa: svakodnevica Srbije na početku trećeg milenijuma, Beograd: ISI FF.

Marković, A. (2019). Prekarnost radnih uslova u Srbiji, u: Lazić, M. i S. Cvejić (ur.). Stratifikacijske promene u periodu konsolidacije kapitalizma u Srbiji. Beograd: Čigoja štampa i ISI FF.

Molnar, D. (2013a). Činjenice o regionalnim razlikama u Srbiji, Kvartalni monitor ekonomskih trendova i politika u Srbiji. Beograd: Fondacija za razvoj ekonomske nauke (FREN), Ekonomski fakultet UB.

Molnar, D. (2013b). Regionalne nejednakosti i privredni rast: primer Srbije. Doktorska disertacija. Ekonomski fakultet UB.

Mrkšić, D. (2000). Restratifikacija i promene materijalnog standarda, u: M. Lazić (ur.), Račji hod, Beograd: Filip Višnjić.

Perrones, D. (2011). Regional disparities and equalities, Towards a capabilities perspective? In: Pike, A., Rodriguez-Pose, A., Tomaney, J. (ur.) Handbook of Local and Regional Development, Routledge, pp. 59-73.

Petrović, I. (2013). Regionalne nejednakosti na tržištu rada u Srbiji: karakteristike nezaposlenosti prema regionima, u: Lazić, M. i S. Cvejić (ur.), Promene osnovnih struktura društva Srbije u periodu ubrzane transformacije. Beograd: Čigoja štampa i ISI FF.

Petrović, M. (2009). Transformacija gradova: ka depolitizaciji urbanog pitanja, Beograd: ISI FF.

Petrović, M. (2014). Društvo i gradovi - između lokalnog i globalnog. Beograd: Čigoja štampa i ISI FF.

Petrović, M., Backović, V., Petrović, I. (2019), Prostorna dimenzija klasnoslojnih razlika u Srbiji: analiza materijalnog položaja i potrošnje u: Lazić, M. i S. 
Cvejić (ur.). Stratifikacijske promene u periodu konsolidacije kapitalizma u Srbiji. Beograd: Čigoja štampa i ISI FF.

Sassen, S. (1991). The Global City: New York, London, Tokyo: Princeton University Press

Tomaney, J. Pike A., A. Rodríguez-Pose (2011). Local and regional development: Reflections and futures. In: Pike, A., Rodriguez-Pose, A., Tomaney, J. (ur.) Handbook of Local and Regional Development, Routledge, pp. 59-73.

Републички завод за статистику (Р3С) (2021a). Регионални бруто домаћи производ, Региони и области Републике Србије, 2019. https://publikacije.stat.gov.rs/G2021/Pdf/G202110115.pdf

Републички завод за статистику (РЗС) (2021b). Трендови, IV квартал, 2020. https://publikacije.stat.gov.rs/G2021/Pdf/G20218001.pdf

Републички завод за статистику (Р3С) (2021c). Анкета о радној снази y Републици Србији, 2020. https://publikacije.stat.gov.rs/G2021/ Pdf/G20215671.pdf.

Стратегија регионалног развоја РС за период од 2007. до 2012. године, https://www.srbija.gov.rs/dokument/45678/strategije-programi-planovi-.php

Уредба о номенклатури статистичких територијалних јединица, 2009. „Сл. гласник РС“, бр. 109/2009 и 46/2010.

Шљукић, М. (2018). Фабрика. Индустија у пост-социјалистичкој Србији, Ново Милешево: Банатски културни центар. 


\author{
Irena Petrović, Vera Backović \\ Spatial dimension of economic inequalities in Serbia: a comparative perspective
}

Summary

Regional disparities in the levels of economic development are indisputable in contemporary societies. Nevertheless, surveys dealing with spatial economic inequalities, as well as its consequences on living conditions and life chances of individuals and social groups, is a rarity, especially in Serbia. The aim of this paper is to analyze certain spatial aspects of economic inequalities in Serbia, but also to compare Serbia with countries in the region and EU countries. In addition to the analysis of income inequalities, regional disparities in the labor market will also be considered. Inequalities will be viewed at the level of different territorial units (regions and areas), ie. statistical territorial units NUTS-2 and NUTS-3. The analysis of inequalities in Serbia will be based on the Labour Force Survey (LFS) conducted by the Statistical Office of the Republic of Serbia. Conducting the survey is based on a standardized methodology for all Member States of the European Union. Regional inequalities in the European Union will be analyzed on the basis of Eurostat data.

Key words: spatial dimension; regional disparities; Serbia; European Union. 


\section{Прилог:}

Табела 1. Бруто домаћи производ у текућим (тржишним) ценама према НУТС - 3 нивоу (најнеразвијеније области)

\begin{tabular}{|l|l|l|}
\hline Земља & Области & У милионима евра \\
\hline Србија & Пиротска област & $\mathbf{4 6 3 . 8}$ \\
\hline Грчка & Fokida & 463.65 \\
\hline Албанија & Berat & 458.26 \\
\hline Хрватска & Ličko-senjska županija & 442.73 \\
\hline Турска & Bayburt & 406.05 \\
\hline Албанија & Dibër & 404.76 \\
\hline Шпанија & La Gomera & 403.11 \\
\hline Албанија & Lezhë & 398.41 \\
\hline Бугарска & Silistra & 395.18 \\
\hline Србија & Зajeчарска област & $\mathbf{3 7 2 . 5 3}$ \\
\hline Бугарска & Vidin & 348.24 \\
\hline Грчка & Lefkada & 303.74 \\
\hline Србија & Тoпличка област & $\mathbf{3 0 3 . 5 1}$ \\
\hline Албанија & Gjirokastër & 275.66 \\
\hline Албанија & Kukёs & 218.35 \\
\hline Албанија & El Hierro & 191.72 \\
\hline Грчка & Evrytania & 189.33 \\
\hline
\end{tabular}

Извор: Еуростат 